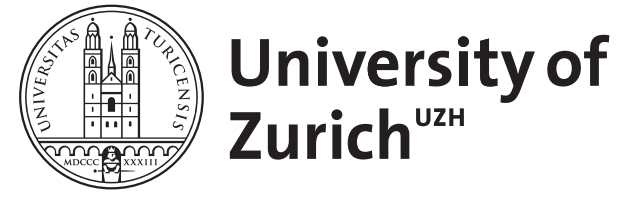

Zurich Open Repository and Archive

University of Zurich

University Library

Strickhofstrasse 39

CH-8057 Zurich

www.zora.uzh.ch

Year: 2015

\title{
Border Tax adjustment - legal perspective
}

Weber, Rolf $\mathrm{H}$

DOI: https://doi.org/10.1007/s10584-015-1414-2

Posted at the Zurich Open Repository and Archive, University of Zurich

ZORA URL: https://doi.org/10.5167/uzh-122366

Journal Article

Published Version

Originally published at:

Weber, Rolf H (2015). Border Tax adjustment - legal perspective. Climatic Change, 133(3):407-417.

DOI: https://doi.org/10.1007/s10584-015-1414-2 


\title{
Border Tax adjustment - legal perspective
}

\author{
Rolf H. Weber ${ }^{1}$
}

Received: 15 August 2014 / Accepted: 18 April 2015 / Published online: 30 April 2015

(C) Springer Science+Business Media Dordrecht 2015

\begin{abstract}
Border tax adjustment is a second-best solution for improving climate mitigation measures as long as international cooperation does not function to a satisfactory degree. However, the implementation of such measures can legally be problematic under the angle of the legal framework of the World Trade Organization (WTO) which aims at liberalizing international trade and at avoiding trade barriers. In particular, border tax adjustment might come into conflict with the National Treatment principle and the discipline on subsidies. These legal problems can only be overcome if the specific legal justification reasons provided for in WTO law for the promotion of climate sustainability (such as conservation of exhaustible resources and protection of human, animal or plant health) are interpreted in a broad way.
\end{abstract}

\section{Introduction}

Climate Change can only be stopped and its damages limited if all states adopt a common approach and take joint action to cut greenhouse gas (GHG) emissions. More than two decades have passed since the world community acknowledged this need and established the United Nations Framework Convention on Climate Change (UNFCCC) in 1992. Based on the UNFCC the Kyoto Protocol (KP) was concluded in 1997, which commits its member states to legally binding emission reduction targets. Nowadays, however, limited membership (major industrialized countries like the US, Canada, Japan and New Zealand have withdrawn) prevents the KP to reach ambitious reduction goals and gives rise to justifiable doubts as to whether the $\mathrm{KP}$ is the right legal instrument to combat climate change. A comprehensive follow-up agreement is planned to be negotiated until 2020, however, chances of success are uncertain.

In the course of the post-Kyoto negotiations, nation states tend to resort to unilateral action to combat climate change. In developed countries, the concept of restricting trade through imposing taxes on carbon-intensive product imports ("Border Tax Adjustments", BTA) has

This article is part of a Special Issue on "Climate Justice in Interdisciplinary Research" edited by Christian Huggel, Markus Ohndorf, Dominic Roser, Ivo Wallimann-Helmer.

Rolf H. Weber

rolf.weber@rwi.uzh.ch 
increasingly gained attention: The term BTA was first defined by a working group of the Organisation for Economic Co-operation and Development (OECD) as "any fiscal measure that put into effect, in whole or in part, the destination principle" (Report of the Working Party, L/3464). Whereas taxes are generally levied according to the origin principle, BTA are raised in the country of destination. Since the term BTA can be misleading (also other fiscal measures than taxes can be adjusted and adjustment does not always take place at the border), scholars also refer to terms like "carbon equalization measures" (Pauwelyn 2009), "Border Adjustment Measures" (BAMs) or "Border Carbon Adjustments" (BCAs).

BTA can mainly be realized by way of three models, namely (i) the levying of carbon taxes on products from countries with lower production standards (import BTA), (ii) the refund of domestic taxes on exported products (export BTA) and (iii) the requirement to obtain emission allowances and to participate in an Emission Trading System (ETS) (Kaufmann and Weber 2011). It is worth mentioning that countries are not obliged to apply import and export BTA symmetrically. Consequently, a government is free to determine whether to design BTA measure so as to apply on imports and/or on exports and whether the measure should be coupled to an emissions allowance system (Cottier et al. 2013).

Domestic measures such as BTA are a unilateral answer to the stagnation of multilateral solutions. Unilateral action is not prohibited in international climate change law. The KP calls upon their members to "implement and/or further elaborate policies and measures in accordance with its national circumstances" such as enumerated in the Art. 2.1(a)(i)-(viii) KP. Furthermore, developing Parties to the Protocol have agreed to take "Nationally Appropriate Mitigation Actions" (NAMAs), referring to mitigation measures to reduce GHG emissions "in a manner commensurate with their capacity and in line with their national development goals" (FCCC/CP/2012/8/Add.1).

The limits to unilateral action are drawn in Art. 3.5 UNFCCC, which states that "measures taken to combat climate change including unilateral ones, should not constitute a means of arbitrary or unjustifiable discrimination or a disguised restriction on international trade". This provision establishes the link from international climate change law to international trade law. Notwithstanding their (arguably) beneficial impacts on GHG reduction, BTA measures run the risk of being in violation with the rules of international trade law, namely the legal framework of the World Trade Organization (WTO law). WTO member states are obliged to adhere to strict non-discrimination rules of national treatment and most-favoured-nation treatment (MFN) and have to refrain from trade-distortive subsidization of exports.

This paper will focus on the legal uncertainties of BTA and only briefly touch upon the economic and social problems that BTA entail. Section 2 starts with examining issues arising in the conflicting area of climate change and competitiveness and in this context illuminates the rationale of BTA. Section 3 addresses issues with regards to WTO law and outlines the provisions relevant with regards to BTA, presenting a test for WTO-compatibility. Finally, section 4 concludes with a brief summary and an outlook on the possible design and implementation of BTA.

\section{Climate change and competitiveness concerns}

\subsection{Regulating global public goods}

Climate change mitigation is the typical global public good: each country's GHG emissions contribute cumulatively to the increase of the overall concentration. Global public goods are 
typically defined through two qualities that stem from their public nature (Weber and Menoud 2008): Everybody can derive benefits from the provision of such goods since they are i) nonrivalrous in consumption and ii) non-excludable. On a global scale, public goods should benefit humanity as a whole, meaning that public goods ideally fulfil three criteria, namely (i) a geographically broad scope (benefits to more than one group of countries or regions), (ii) a social-economic extension (a broad spectrum of the global population, crossing manifold segments), and (iii) a generational criterion (benefit to the present generations without jeopardizing the ability of future generations to meet their own needs).

Moreover, global warming presents a classic example of the "tragedy of the commons". Despite the fact that countries acknowledge the problem (global warming) and the need of a solution (a global, legally binding treaty), negotiations often fail for the sole reason that member states cannot agree on fair distribution (who has to commit to what kind of mitigation actions) and due to the fact that costs for climate change mitigation prevail short-term (political) benefits and governments are reluctant to cover the costs.

Rules implementing higher climate protection standards usually cause costs and measures aiming at GHG reduction can have an impact on the international competitiveness of firms. Since domestic businesses are obliged to comply with such environmental regulations, they might have to bear costs which are not to be borne by foreign firms. Consequently, legal rules should be designed in a way that competitiveness is boosted or at least not jeopardized (Pauwelyn 2007).

\subsection{BTA: reconciling climate change and competitiveness?}

Usually competitiveness provisions are motivated by economic reasons. Arms-length competition requires rules to level the playing field. Within the context of climate change mitigation this would imply that domestic and foreign firms either have to meet equivalent environmental standards or that disparities with regard to such obligations can be offset. Apart from economic rationales, non-economic reasons are to be taken into account (Pauwelyn 2007; Lay 2012; Weber 2014): Firstly, climate change "is the greatest and widest-ranging market failure ever seen" (Stern Review 2006) and environmental standards should internalize the social cost of carbon. Secondly, competitiveness rules can be an instrument to avoid market-shifts to "dirtier" producers by dis-incentivizing emission migration and relocation of firms. Finally, since competitiveness rules force importers of carbon intense products to pay the social cost of carbon, energy-intensive domestic industries might be inclined to accept stricter national environmental policies and more countries might be encouraged to commit to international efforts to reduce GHG emissions. Within this context, BTA are often regarded as an instrument to address economic and non-economic concerns, since they are generally driven by four rationales.

(a) Carbon leakage

The concept of BTA is the best-known measure to offset lax environmental standards in cross-border trade, implemented in order to prevent so-called carbon leakage. This term is used to describe the phenomenon of companies from countries with high environmental production standards moving their production seat to another country with laxer regulation on GHG emissions, in order to escape the additional cost burden imposed by climate policies. Carbon leakage is dangerous for at least two reasons: First, it could lead to an overall increase of worldwide emissions, and secondly, it jeopardizes competitiveness and economic development of a country and leads to the loss of jobs. 
(b) Level playing field

BTA can serve as a device to ensure a level playing field between countries with high and such with lax or no environmental policies: Through imposing taxes on imported products or through the rebate of export products from an additional fiscal burden, BTA are thought to offset price inequalities and to restore cross-border competitiveness.

Rules implementing higher climate protection standards cause costs for producers of that country and eventually lead to higher product prices for consumers in the home market. Foreign producers in countries without environmental regulations can offer the same products to a lower price and thereby gain a competitive advantage. There are many reasons why national rules for climate change mitigation should be designed in a way that the competitiveness is not jeopardized (Pauwelyn 2007), in order to avoid carbon leakage and market distortions. Against the background of nation states operating unilaterally without a multilaterally binding agreement based on consensus, it is difficult to reach arms-length competition with domestic and foreign firms having to meet the same environmental standards. Competitiveness rules could gap the bridge through offsetting price-inequalities and restoring cross-border competitiveness.

(c) Leverage

A further motivation behind BTA is the idea that through rules on competitiveness forcing importers of "dirtier" products to pay the social cost of carbon, energy-intensive domestic industries might also be inclined to accept stricter national environmental policies (leading to a reduction of emissions) and more countries might be incentivized to join international efforts in order to cut emissions.

(d) Distributive justice

Apart from competitiveness as such, considerations about distributive justice are to be taken into account: Distributive justice and social awareness are elements of a broadly understood concept of global public goods. Derived from such an approach, the question must be addressed to what extent individuals do have a moral duty to refrain from causing climate change problems. Carbon leakage as an aspect of competitiveness does also have an impact on fairness, requiring cooperation in order to mitigate negative consequences of climate change.

\subsection{Challenges and risks}

Notwithstanding these advantages, competitiveness rules such as BTA are not a panacea; they can also cause costs on a national and a global level and bear significant social and political risks (Pauwelyn 2007; Weber 2014).

(a) Costs

Competitiveness rules bear the risk of amounting to technical barriers to trade. Such barriers are inefficient in many ways, since they add costs to the production, which will usually be paid as part of the product price by domestic consumers. Moreover, technical barriers run the risk of violating WTO law (see infra 4.2.c). Apart from being costly, the implementation of competitiveness rules is usually complex and accompanied with complicated administrative burdens.

From an economic point of view, it must be added that competitiveness rules like BTA measures are only a "second-best solution": Market-based approaches, like emission 
trading systems or labelling schemes are more desirable, since they allow for an efficient allocation of resources and encourage environmental-friendly behaviour through price incentives rather than through regulatory pressure, thereby aligning financial interests and environmental aims for businesses and individuals.

(b) Undermining multilateralism

Unilateral actions run the risk of undermining the trust necessary for future international cooperation and even lead to countervailing actions and trade disputes. This danger is even more apparent considering the fact that competitiveness rules may also be used as protectionist tool, if the main motivation behind such rules is neither competition nor climate change, but purely protectionist purposes. Such a disguised restriction of international trade would run counter WTO law and can be challenged before the WTO Dispute Settlement Body (DSB).

(c) Common but differentiated responsibilities

Moreover, offsetting measures such as BTA are very controversial from a development perspective: Countries with poor environmental standards are often developing and least developed countries (LDCs). According to the UNFCCC's principle of Common but Differentiated Responsibilities (CBDR) developed countries should "take the lead in combating climate change and the adverse effects thereof" (Article 3.1 UNFCCC). The rationale behind this principle is that developed countries bear a bigger historical responsibility for global warming. A "punishment" in form of an additional financial burden, which BTA would impose on developing countries or LDCs, would be in stark contradiction to the generally acknowledged CBDR principle and further jeopardize the already fragile political climate of UNFCCC negotiations.

\section{WTO law challenges}

Any kind of BTA causes additional costs to the importers of goods. Since these costs can have a negative impact on cross-border trade and even constitute measures with extraterritorial effects, they fall within the scope of WTO law and have to be assessed in the light of the applicable rules.

There are different WTO obligations that might be relevant to BTA. At the heart of the analysis of WTO compatibility lays the question, whether a regulatory distinction between products based on their environmental footprint violates the non-discrimination obligations set forth mainly in Article I and III, but also in Article II of the General Agreement on Tariffs and Trade (GATT). Furthermore, the question arises whether export BTA amount to an export subsidy prohibited by the Agreement on Subsidies and Countervailing Measures (SCM Agreement). Apart from these central questions, the test on WTO compliance will briefly touch upon the increasingly important issue of the legal status of process and production methods (PPM).

\subsection{Most favoured nation principle}

The most-favoured-nation principle (MFN) enshrined in Article I:1 GATT is one of the two key pillars of WTO law. As interpreted by the Appellate Body (AB) in Canada-Autos, this provision obliges member states not to discriminate between like products originating in or destined for different countries (WT/DS139/AB/R, WT/DS142/AB/R, para 84). 
BTA do not run the risk of violating the most favoured nation (MFN) principle: tax measures usually do not distinguish along the lines of the origin of the product; the regulatory distinction is rather based on carbon concerns.

\subsection{National treatment}

The national treatment obligation is the second key-concept of WTO law. It prohibits members from treating imported products less favourably than like domestic products. WTO law does not contain any provision dealing directly with BTA. The GATT, however, distinguishes between "internal taxes and charges" in Article III GATT and "other duties or charges of any kind imposed on or in connection with the importation" (import duty) according to Article II:1(b) GATT second sentence. Consequently, if the BTA measure at issue qualifies as a tax, it falls within the scope of Article III:2 GATT and has to meet the criteria set forth therein. If a challenged measure classifies as an import duty, a test according to Article II GATT applies.

\section{(a) Article III:2 of the GATT}

Since BTA can be regarded as "internal taxes or internal charges of any kind", Article III:2 GATT applies, requiring member states not to apply such taxes or internal charges (i.e., BTA) "in excess of those applied directly or indirectly to like domestic products." Consequently, a carbon tax on imports cannot be levied without an equivalent domestic tax (Hufbauer et al. 2009). A key issue is the question of the likeness of products: only "like products" need to be treated equally. If a WTO Panel or Appellate Body was to judge that two products at issue were not "like", a claim of violation of the national treatment principle will not be pursued.

As defined by the Working Party on Border Tax Adjustments (BISD 18S/97) and reiterated repeatedly in WTO jurisprudence, likeness is assessed based on four criteria: (i) physical characteristics of a product, (ii) its end-uses, (iii) the competitive relationship, and (iv) the consumer preferences. Traditionally, the Appellate Body has interpreted the notion of "like products" broadly (Kaufmann and Weber 2011; Lay 2012) putting emphasis rather on the first three of the criteria. However, in a case where the AB had to adjudicate upon a French export ban on asbestos, the AB for the first time acknowledged the importance of consumer preferences: It found that products containing asbestos cannot be considered to be like "asbestos-clean" products, due to obvious health reasons (WT/DS135/AB/R of March 12, 2001).

In addition to the assessment of "likeness", the test under Article III:2 GATT implies an assessment of the tax at issue: when the tax on foreign products is "in excess" of the tax for like domestic products, a violation of Article III:2 will be assumed. Whether a tax is "in excess", must be determined based on the actual and not the nominal tax burden (Panel Report, Argentina - Hides and Leather, WT/DS155/R, from 19 December 2000, paras. 11.182-11.184). As reinforced by the AB in Japan - Alcoholics a strict test applies and "even the smallest amount of 'excess' is too much" (WT/DS8/AB/R, WT/DS10/AB/ R, WT/DS11/AB/R, 4 October 1996, p. 23). Therefore, a national government should be cautious when determining the amount of the BTA, taking particular care to avoid levying a higher carbon tax on imported products than on domestic ones.

(b) Article II:2(a) of the GATT

According to Article II GATT, member states are bound to a maximum limit of certain tariffs in exchange for similar tariff reductions by their trading partners, as set forth in 
their Schedule of Concessions annexed in GATT 1994. Article II:1(b) GATT requires products benefiting from a bound tariff concession to be "exempt from ordinary customs duties as well other duties or charges of any kind in excess of those set forth and provided in the tariff schedules". As clarified by the AB in India - Additional Import Duties, the application of quantitative restrictions, such as tariffs or other customs duties, is in principle prohibited, but may nevertheless be permissible under Article II:i(b) "so long as they do not exceed a member's bound rates" (WT/DS360/AB/R, 30 October 2008, para. 159). The $\mathrm{AB}$ further found that "charges that are not in justified under Article II:2(a) GATT are not in breach of Article II:1(b) GATT" (WT/DS360/AB/R, 30 October 2008, Fn. 320).

Article II:2(a) GATT allows the imposition of two types of import charges: (i) "Charges equivalent to an internal tax consistently with Article III:2 GATT" imposed on imported products that are like domestic products and (ii) charges imposed on "articles from which the imported product has been manufactured or produced in whole or in part" (Kaufmann and Weber 2011). Therefore, a BTA measure challenged under the first sentence of Article II:2(a) GATT would have to be tested under the same criteria as under Article III:2 GATT (see above) in order to determine whether it was applied "in excess of" the internal tax .

(c) Article 2.2 TBT Agreement

A similar line of argument looks at the assessment of environmentally preferable products as technical regulations or standards under the Technical Barriers to Trade (TBT) Agreement. WTO member states are obliged to consider their nondiscrimination obligation when adopting technical regulations. According to Article 2.2 TBT Agreement, member states "shall ensure that technical regulations are not prepared, adopted or applied with a view to or with the effect of creating unnecessary obstacles to international trade". (Hsueh 2013). The Appellate Body has interpreted Article 2.2 TBT Agreement in the US - Certain Country Of Origin Labelling (COOL) case (WT/DS 384/ $\mathrm{AB} / \mathrm{R}$ of June 29,2012 ) quite strictly. As a consequence, a country intending to increase the level of environmental protection would bear the burden of proof to demonstrate that such measures do not constitute technical trade barriers. Insofar, a more liberal interpretation of terms such as "legitimate objective of measures" appear to be necessary in order to give incentives to countries implementing rules for environmentally sensitive production methods (Weber 2014; Hsueh 2013).

\subsection{Process and production methods}

Process and production methods (PPM) look at the origins of products, i.e., at the way in which they have been processed or produced. Article III:2 GATT reads as follows: "products ... shall not be subject, directly or indirectly..." which has been interpreted as enabling the adjustment of taxation of inputs in the final product. Generally speaking, however, the differentiation between products according to PPM is controversially debated and existing case law would suggest that discriminatory measures based on PPM are not permitted without reservation under the GATT (Kaufmann and Weber 2011). In the case of US - Tuna (Mexico), the GATT Panel distinguished between measures that "affect products as such" and measures that do not (DS21/R, 3 September 1991, unadopted, BISD39S/155). The Panel's approach has led to the understanding that PPM are only to be considered in the assessment of products' 
likeness if they manifest themselves in the "products as such". In other words, product-related PPM-based measures are applied in order to guarantee the quality, safety, and functionality of the product and are usually directly detectable in the end product (Kaufmann and Weber 2011).

The qualification of non-product-related PPM-based measures, such as the amount of energy consumed in the manufacturing process or environmentally friendly production standards, are more controversial. The root of the debate has to be seen in the fact that, by limiting the imports of products compounded in a specific manner, exporters from other countries may face difficulties to access such a market, as they have to adapt their domestic PPM in order to comply with specific requirements called for/by the importing State.

The WTO's finding in the Asbestos case that fundamental human health risks are relevant when assessing the likeness of products was conceived as an important signal, suggesting that the GATT can be interpreted in a way that allows domestic environmental regulations for imported goods based on environmental concerns. This interpretation would imply that the importation of a carbon intensive product may be restricted without violating the national treatment obligation. This interpretation is further reiterated by a former GATT Panel which in a case concerning automobile taxes found that high-fuel efficient cars are not "like" gasguzzling cars (DS31/R of October 11, 1994).

However, the WTO case law mentioned above does not reveal whether other policy objectives such as the protection of the environment or human health considerations in more general terms could also be considered when examining the likeness of products. Another reservation concerns the health risks as such: in certain cases (for example asbestos) the risks are internationally acknowledged by experts, whereas the assessment of more controversial substances might lead to debates. Therefore, it is not completely clear yet to what extent environmental policies may influence the likeness of products (Kaufmann and Weber 2011).

As a consequence, no prediction can be made as to whether and how the debate on PPM will be solved in the BTA context. Instead, by doing the examination of the competitive relationship between comparable products as a criterion for likeness a special focus should be set on consumer preferences. If consumers distinguish between products based on the applied PPM, irrespective of whether these are product or non-product related, it seems to be justified to consider PPM in the assessment of "like products" (Kaufmann and Weber 2011). However, the burden of proof to demonstrate the existence of such prevalent consumer-preferences would lie on the responding party.

\subsection{Subsidies}

Governmental financial support or fiscal incentives can also cause problems under the SCM Agreement of the WTO. During the time period between 1995 and 1999, environmental subsidies promoting sustainability of production were exempted from the WTO legal disciplines. This exemption, however, expired at the beginning of 2000 without being renewed and therefore, countries now have only limited tools to encourage industries to adapt greener technologies or promote environmentally preferable products.

The WTO AB has emphasized that countries, in principle, have the sovereign authority to levy taxes and also to relieve certain categories of revenues from taxes. But notwithstanding this sovereignty, the member states have the duty to respect their WTO obligations (WT/DS108/AB/R, 24 February 2000, para. 90). Favourable tax treatment and other fiscal incentive can qualify as a "subsidy" within the meaning of the SCM Agreement, if two criteria are met: The tax exemption is a "government revenue that is otherwise due" (Article 
1.1.(a)(1)(ii) SCM Agreement) and confers a benefit to the person or company excluded from the tax (Article 1.1.(b) SCM Agreement). As stated by the Panel and reiterated by the AB in US FSC the term "otherwise due" implies a "but for test", i.e., a comparison based on "the situation that would prevail but for the measures in question" (WT/DS108/R, Panel Report from 8 October 1999, para. 7.45). Since export BTA are tax rebates that are granted "but for" the BTA measure, they qualify as "revenue otherwise due". Furthermore, the tax relief confers a "benefit" (Article 1.1.(b) SCM Agreement) to the exporter, since it leaves him "better off" compared to other market actors. Therefore, BTA measures meet both criteria of Article 1.1. SCM and can be challenged under the SCM Agreement.

Nevertheless, the SCM Agreement does not prohibit subsidies per se, only subsidies contingent upon export performance or import substitution subsidies are illegal (Article 3 SCM Agreement). However, there is a high probability that a challenged BTA measure would fall under the category of export subsidies, since BTA usually directly and de lege aim at exempting exporters from tax duties that non-exporting market actors bear.

\subsection{Legal justifications for trade barriers}

If BTA are critical in view of the application of the WTO principles, the question arises whether justification reasons can be applied. WTO law contains a list of specific justifications contained in Article XX GATT and Article XIV of the General Agreement on Trade in Services (GATS). If a measure is motivated by one of the listed justification reasons, it is considered to be legitimated, even if it violates WTO-law. The list of reasons is based on justified non-trade policies, provided that such interests are adequately balanced against the objective of free trade (Kaufmann and Weber 2011; Lay 2012).

With regards to BTA, two justification reasons aiming at environmental protection and sustainability might apply: The first provision exempts measures aimed at the "conservation of exhaustible resources" (Article XX(g) GATT), the second one those "necessary for the protection of human, animal or plant life or health" (Article XX(b) GATT). However, justification under Article XX(g) GATT is likely to fail, since it would be difficult for a respondent to prove a strong nexus between the challenged BTA measure and the conservation of exhaustible resources. Also justification under Article XX(b) GATT is uncertain: Traditionally, the WTO Panels and the AB have interpreted the scope of these justification reasons rather narrowly and have been reluctant to accept justifications based on human, animal or plant health (see for example Brazil-Retreaded Tyres, WT/DS332/AB, adopted 17 December 2007).

Even if specific BTA measures fall under any of the listed justification reasons, such a measure still has to be necessary and proportional. In the previous WTO jurisprudence, environmental or health policy choices made by countries have not been challenged if the application of the respective policies was necessary and proportional and if there was no alternative reasonably available. Consequently, the focus must be put on the relationship between the measure at stake and the legitimate environmental policies; a country needs to demonstrate that the measure is apt to produce a substantial contribution to the achievement of its objective (Kaufmann and Weber 2011).

Established jurisprudence gives good guidelines on how to structure and design the necessity/proportionality test implying different steps: (i) The concerned country has to determine whether the measure is indispensable to reach the policy goals. The measure is only acceptable if no other less restrictive means are readily available. Depending on the given 
circumstances, however, this criterion is not always easy to fulfil. (ii) If the measure is not indispensable or its efficiency cannot be proven, the second step of the proportionality test applies: the public policy interest of protecting the resources or human health needs to be balanced against the interest of liberalized trade. The weight of sustainability considerations/ environmental needs must be higher than the benefits of trade. This test can rely on international agreements and resolutions such as the UNFCCC Framework, the Kyoto Protocol or further agreements, which emphasize that member states shall give particular relevance to climate change considerations. (Kaufmann and Weber 2011).

Finally, the measure must be applied so as not to create an arbitrary or unjustified discrimination or as not to lead to disguised restrictions on international trade as required by the Chapeau of Article XX GATT (Lay 2012; Weber 2014).

\section{Conclusion}

BTA are a controversial matter, from a legal as well as from an ecological, economic and political perspective. This paper focused on the legal uncertainties of the issue and has carried out a test on WTO compatibility in order to answer the question of how to design BTA in way compatible with international law.

Generally speaking, BTA are legally less problematic when implemented as part of an emission allowances system, for example in the form of the ETS of the European Union (WTO-UNEP Report 2009; Kaufmann and Weber 2011) due to the fact that a trading system is more easily apt to reflect market mechanisms. This reduces the risk of having a market distortive impact and thereby violating WTO law.

However, import BTA which are not implemented through an emission allowance system are also generally permitted under the WTO law, provided they meet certain criteria as set forth in Articles II and III GATT. Therefore, it is important for governments to design BTA as an indirect product tax within the scope of Articles II or III GATT. The design should be such that a "nexus" between the tax and the product is established. Such a nexus exists if carbon taxes aim at creating a level playing field between "like products" in the country of destination (Kaufmann and Weber 2011). Furthermore, such a tax will only be considered compatible with the WTO's national treatment principle, if the tax burden imposed on imported products is not "in excess", i.e., equal in term of the actual tax burden, compared to the tax imposed on domestic products.

Import BTA in violation of WTO law could still be legitimized if considered to fall within the scope of the legal justification reasons provided for in Article XX GATT. WTOincompatible BTA may be justified either on grounds of Article XX(b) GATT ("necessary to protect human, animal or plant life or health") or of Article XX $(\mathrm{g})$ GATT ("relating to the conservation of exhaustible natural resources"). However, the WTO adjudicators have traditionally applied a strict test for these justification reasons, allowing only measures which aim directly at the preponderant public interest at issue and are proportional to be exempt from the non-discrimination obligations.

Even if import BTA were permissible under WTO law, export BTA would very likely be considered to be a prohibited export subsidy in violation of Article 3.1 SCM Agreement. Since the justification reasons in Article XX GATT (arguably) do not apply on subsidies and the SCM Agreement itself does not encompass any justification reasons, a violation of the SCM Agreement could not be justified through preponderant policy objectives, such as environmental concerns. 
However, apart from legal concerns, the overall justification of BTA is disputed: From an economic point of view, market-based instruments (such as emission trading systems or labelling schemes) seem to be more cost-efficient and leave more room for economic development, both for domestic industries as well as for cross-border trade (if designed properly). From a political perspective, BTA run the risk of undermining the multilateral efforts in provoking retaliatory measures and running counter the UNFCCC's CBDR-principle.

Notwithstanding these doubts, climate change is the most crucial global problem of our times. It is widely acknowledged that climate change mitigation and adaption measures are best concluded on an international level through an internationally binding and enforceable legal agreement. However, against the background of missing international consensus and the highly uncertain prospects regarding the conclusion of an international agreement in time, policy makers are under pressure to act. Therefore, second-best solutions are to be considered and the implementation of BTA mechanisms seems to be a viable approach. Indeed, BTA measures, depending on their precise design, run the risk of violating WTO law, particularly the national treatment principle and the rules on subsidies. Thus, countries implementing BTA measures run the risk of being challenged before the WTO dispute settlement mechanism, whose decisions are biding upon Member States. Nevertheless, in recent cases the WTO Panels and $\mathrm{AB}$ have interpreted the justification reasons in a broader way, particularly the "exhaustion of natural resources" (Article XX(g) GATT) and the protection of health (Article XX(b) GATT). In addition, the consequence of not complying with WTO commitments "only" consists in the invalidation of the respective measure; monetary sanctions are relatively unlikely. If this approach would be acknowledged, a certain degree of climate mitigation could be achieved until the international community comes to a "global" understanding of measures to be implemented world-wide.

\section{References}

(2006) The stern review on the economic effects of climate change. Popul Dev Rev 32(4):793-798

Cottier T et al (2013) Border Tax Adjustments, Can energy and carbon taxes be adjusted at the border? Schlussbericht zuhanden des Staatsekretariats für Wirtschaft SECO und der Eidgenössischen Finanzverwaltung EFV

Hsueh CW (2013) A greener trade agreement: approaches to environmental issues to the TPP negotiations. Asian J WTO Int Health Law Policy 8(2):521-542

Hufbauer GC, Charnovitz S, Kim J (2009) Global warming and the world trade system. Peterson Institute for International Economics, Washington

Kaufmann C, Weber RH (2011) Carbon-related border tax adjustment: mitigating climate change or restricting international trade? World Trade Rev 10(4):497-525

Lay A (2012) Massnahmen zum Ausgleich der Kosten des europäischen Emissionszertifikatehandels. Dissertation, University of Zurich

Pauwelyn J (2007) U.S. Federal climate policy and competition concerns: the limits and the options of international trade law. Working paper 07-02, Duke University

Pauwelyn J (2009) Statement of Joost Pauwelyn, testimony before the subcommittee on trade of the house committee on ways and means, US House of Representatives, Washington, DC, 24 March

Weber RH (2014) Designing trade rules to promote climate sustainability. J Energy Power Eng 8:612-619

Weber RH and Menoud V (2008) The information society and the digital divide. ZIK vol. 40, Zurich Geneva

WTO-UNEP Report (2009) Trade and climate change. World Trade Organization, Geneva 